Pesq. Vet. Bras. 37(11):1270-1274, novembro 2017

DOI: $10.1590 / \mathrm{S} 0100-736 \mathrm{X} 2017001100012$

\title{
A randomized, double-blind, placebo-controlled study to assess the effect of an aqueous extract of Triticum aestivum on canine outer ear inflammation ${ }^{1}$
}

\begin{abstract}
Ciciane P.M. Fernandes ${ }^{2 *}$, Alana Hijano ${ }^{3}$, Charles S. Lima ${ }^{3}$, Eduardo G. Fontoura ${ }^{3}$, Renata C. Schramm², Samuel R. Félix ${ }^{3}$ and Márcia O. Nobre ${ }^{3}$

ABSTRACT.- Fernandes C.P.M., Hijano A., Lima C.S., Fontoura E.G., Schramm R.C., Félix S.R. \& Nobre M.O. 2017. A randomized, double-blind, placebo-controlled study to evaluate the effect of an aqueous extract of Triticum aestivum on canine outer ear inflammation. Pesquisa Veterinária Brasileira 37(11):1270-1274. Departamento de Clínica Veterinária, Faculdade de Veterinária, Universidade Federal de Pelotas, Campus Universitário Capão do Leão, Pelotas, RS 96010-900, Brazil. E mail: cici.marten@gmail.com

Outer ear otitis is a multifactorial acute or chronic inflammation of the ear canal, and treatment is often hampered by growing antibiotic resistance. Pre-clinical assessments have shown that an aqueous extract of Triticum aestiveum (wheat) can effectively reduce the symptoms associated with the disease. The purpose of this study was to assess, through a randomized, double-blind, placebo-controlled trial, the use of T. aestivum extract on canine external otitis. Thirty dogs (60 ears) met the criteria to be included in this study, and were randomly assigned a treatment group: placebo, extract, or positive control $(\mathrm{C}+)$. Ears were treated every day for seven days, and assessed before treatment (day zero), after treatment (day 7), and again on reassessment (day 14). Clinical assessment included: type of otitis; pinna conformation; presence or absence of itchiness, foul odor, and pain; presence of stenosis, erythema and cerumen. Furthermore, the evaluators assessed the temperature in each ear and the $\mathrm{pH}$ of the cerumen, and swabs were collected for bacterial and fungal isolation. All veterinarians treating and assessing the animals were blinded regarding the treatment groups. Results showed little difference in the treatment groups regarding clinical parameters. By day 7 ears treated with the $\mathrm{C}+$ had elevated temperatures, when compared to the others $(\mathrm{P}<0.05)$, this was still true on day 14 . Bacterial isolation had completely died out by day 7 , however, on day fourteen the placebo group had six ears with bacterial infections, unlike the other two groups $(\mathrm{P}<0.05)$. The results generated herein show that a $25 \%$ wheat extract solution is effective in the reduction of clinical and microbiological parameters of external otitis, with better results when compared to a placebo, and similar results to the traditional, antibiotic/anti-inflammatory treatment.
\end{abstract}

INDEX TERMS: Ear inflammation, Triticum aestivum, dog, treatment.

RESUMO.- [Ensaio clínico, randomizado, duplo cego, para tratamento experimental de otite externa com extrato aquoso de Triticum aestivum.] A Otite Externa

\footnotetext{
${ }^{1}$ Received on September 2, 2016.

Accepted for publication on September 4, 2016.

${ }^{2}$ Departamento de Clínicas Veterinária, Faculdade de Veterinária, Universidade Federal de Pelotas (UFPEL), Campus Universitário Capão do Leão, Pelotas, RS 96010-900, Brasil. *Autor para correspondência: cici.marten@gmail.com

3 Departamento de Veterinária Preventiva, Faculdade de Veterinária, Universidade Federal de Pelotas (UFPEL), Campus Universitário Capão do Leão, Pelotas, RS 96010-900, Brasil.
}

(OE) é uma inflamação aguda ou crônica do conduto auditivo dos cães apresentando várias etiologias e o uso de antimicrobianos vem apresentando resistência por inúmeras causas. 0 objetivo do presente estudo clínico, randomizado e duplo cego foi avaliar a utilização de Triticum aestivum no tratamento da otite externa em cães. Trinta cães com sintomas de otite externa foram distribuídos aleatoriamente em três grupos para tratamento (grupo placebo, grupo solução teste e grupo controle positivo), sendo tratados uma vez ao dia, durante sete dias e avaliados nos dias 0 (zero), sete, e 14 pós o tratamento, sendo submetidos a exame otológico, coleta de secreção auricular para cultura bacte- 
riana e medição do pH do canal auditivo, sendo também realizada a aferição da temperatura do conduto auditivo. Como resultados foi observado que no dia sete houve um aumento da temperatura auricular do grupo controle positivo e manteve-se com a temperatura maior no dia $14 \mathrm{em}$ relação aos demais grupos. Em relação a cultura bacteriana não houve diferença estatística nos grupos entre os dias zero e sete, porém na avaliação com 14 dias, percebeu-se crescimento bacteriano somente no grupo placebo. A solução com extrato aquoso de trigo $25 \%$ é eficaz na redução dos parâmetros clínicos e microbiológicos da otite externa, sendo uma nova opção para o tratamento dessa enfermidade em cães.

TERMOS DE INDEXAÇÃO: Otite externa, Triticum aestivum, canino, tratamento.

\section{INTRODUCTION}

Outer ear otitis is an acute or chronic inflammation of the ear canal, which develops in the proximal portion of the pinna (Lozina et al. 2010). It is one of the most common diseases in small animal practice, characterized by clinical signs such as: itchiness, erythema, pain, and a large amount of cerumen (Plischke \& Pereira 2012). The disease has a multifactorial etiology, and treatment is often hampered by growing antibiotic resistance (Lozina et al. 2010, Malayeri et al. 2010, Ziech et al. 2013).

Wheat, Triticum aestivum (sin. T. vulgare) (Tillmann et al. 2014), is a grass of the Poaceae Family (Whent et al. 2012). Several therapeutic properties have been attributed to this plant, such as wound healing (Tillmann et al. 2014), antioxidant (Souza et al. 2006), and antibiotic (Ribas et al. 2005, Godeiro et al. 2010), among others. In light of these properties, the purpose of this study was to assess, through a randomized, double-blind, placebo-controlled trial, the use of T. aestivum extract on canine external otitis.

\section{MATERIALS AND METHODS}

Plant extract. The wheat (Triticm aestivum) plant was manually harvested in October 2013, in the municipality of Jaguarão, Rio Grande do Sul state, Brazil (32 $33^{\prime} 58^{\prime \prime}$ S, 5322'33' W, altitude $26.00 \mathrm{~m}$ ). A sample was sent to the herbarium of the federal university of Pelotas (Universidade Federal de Pelotas - UFPel), for identification and cataloging. The plant was then dried and milled, and the extracts were obtained in the oleochemistry laboratory in the same university (Laboratório de Oleoquímica e Biodiesel do Centro de Ciências Químicas, Farmacêuticas e de Alimentos da UFPel), through the ultrasound depletion method. The milled plant was added to ultrapure water in a proportion of $1 \mathrm{~g}: 1 \mathrm{~mL}$, and bath sonicated for 30 minutes. The major componentes found in this extract were: quercetin $(77 \mathrm{mg} / \mathrm{g})$, kaempferol (163mg/g), apigenin (38mg/g) and carnosic acid (117mg/g). The extract was characterized by HPLC as previously described (Tillmann et al. 2014).

Clinical trial. The clinical trial was conducted in the month of January 2014, in a nonprofit institution in the city of Capão do Leão, RS. The study protocol and all animal manipulation were approved by UFPel's ethics committee (CEEA-UFPel 4639-2014) and the institutions management, and those responsible for each dog were informed of all procedures and risks, and asked to sign consent forms.
To be included in this study (inclusion criteria) dogs of either sex had to have two years or more, no defined breed (breedless) and present signs suggestive of external otitis. Dogs that met these criteria were excluded (exclusion criteria) if they had any other ailment; if the otitis had parasitological involvement; presence of nodular masses (polyps or tumors) in the ear canal; and pregnant females.

This study used three possible treatment groups. The Placebo (named "A" during the experimental period) received topic treatment with a solution of $25 \%$ saline and $75 \%$ propilenoglicol. The experimental wheat solution group (named "B" during the experimental period) received a solution of $25 \%$ aqueous wheat extract and $75 \%$ propilenoglicol. The positive control (named "C" during the experimental period) received commercial otitis treatment $\left(\right.$ Otomax $\left.^{\circledR}\right)$. From here on these groups will be called Placebo, Extract, and $\mathrm{C}+$, respectively.

Dogs that met the criteria to be included in this study were then randomly allocated in three different groups, according to the treatment they would receive. Treatment bottles were labeled A, B, or C, and all manipulators were blinded to the treatment groups. The animals were treated once a day for seven days, and assessed on days 0 (zero), seven, and 14 post treatment. The evaluators assessed the following criteria: type of otitis (ceruminous or purulent); pinna conformation (erect, semi-erect, and pendular); presence or absence of itchiness, foul odor, and pain. Using an otoscope the evaluators assessed the presence of stenosis, erythema and cerumen. the evaluators also assessed the temperature in each ear, using an infrared ear thermometer $\left(\mathrm{Omron}{ }^{\circledR}\right.$ Mini Instant Ear Thermometer, MC-510NT, $\pm 0,2^{\circ} \mathrm{C}$ ).

After the clinical evaluation, three samples from each ear were obtained using sterile swabs. These were sent to the lab for fungal and bacterial isolation, and to measure the $\mathrm{pH}$ of the wax. Bacterial isolation was attempted by culture in blood agar for 48 hours at $37^{\circ} \mathrm{C}$. Positive cultures were characterized through micromorphology and biochemical assessment. For the $\mathrm{pH}$, the tip of the swab was cut into $15 \mathrm{~mL}$ ultrapure water, shaken (in vortex) for 10 seconds, and read in a Tecnopon ${ }^{\circledR} \mathrm{pH}$ reader.

Only two veterinarians treated all the animals to avoid different outcomes. All assessments were made by three different evaluators. All participants, both those responsible for treatment and those responsible for assessment, were blinded to the treatment groups.

Statistical analysis were conducted in the Statistix 9.0 or GraphPad software. Continuous data were analyzed using ANOVA or T-tests. When necessary, multiple comparisons were made using Tukey. Qui-Square was used to compare categorical data.

\section{RESULTS}

A total of 340 dogs were analyzed; 30 (60 ears) of these met the inclusion criteria. Fourteen $(46.6 \%)$ of these dogs were males, and 16 (53.3\%) were females. In the sample, 10 dogs were adults (aged 1 to 6 years), and 20 were older than 7 years. With regard to the shape of the acoustic shell, $13(43.33 \%)$ dogs had pendular ears, 13 (43.33\%) had semi-erect ears, and 4 (13.33\%) had erect ears. With regard to the cerumen type, $56(81.6 \%)$ of the 60 ears analyzed had ceruminous otitis, and $4(6.6 \%)$ dogs had purulent otitis. In all studied animals, both ears presented with the same type of otitis.

The comparison among the groups at the first evaluation (day zero) indicated no significant difference in pruritus, fetid odor, otalgia, erythema, stenosis, and the amount of cerumen (Ls 1 and Fig.1). Seven days after treatment, the 
temperature of the ears treated with $\mathrm{C}+$ increased by more than one degree. This result was not observed in the other groups (extract and placebo, Fig.1A). Fourteen days after the initiation of treatment, the temperature of the ears treated with $\mathrm{C}+$ was still higher than that in the ears treated with placebo (Fig.1A).

The differences in the bacterial count before treatment (day zero) were not statistically significant among the groups. The isolated bacteria included coagulase-negative Staphylococcus, Pseudomonas sp., Proteus sp., and Staphylococcus intermedius (Fig.2). Seven days after treatment, a new bacteriological evaluation was performed in the ears,

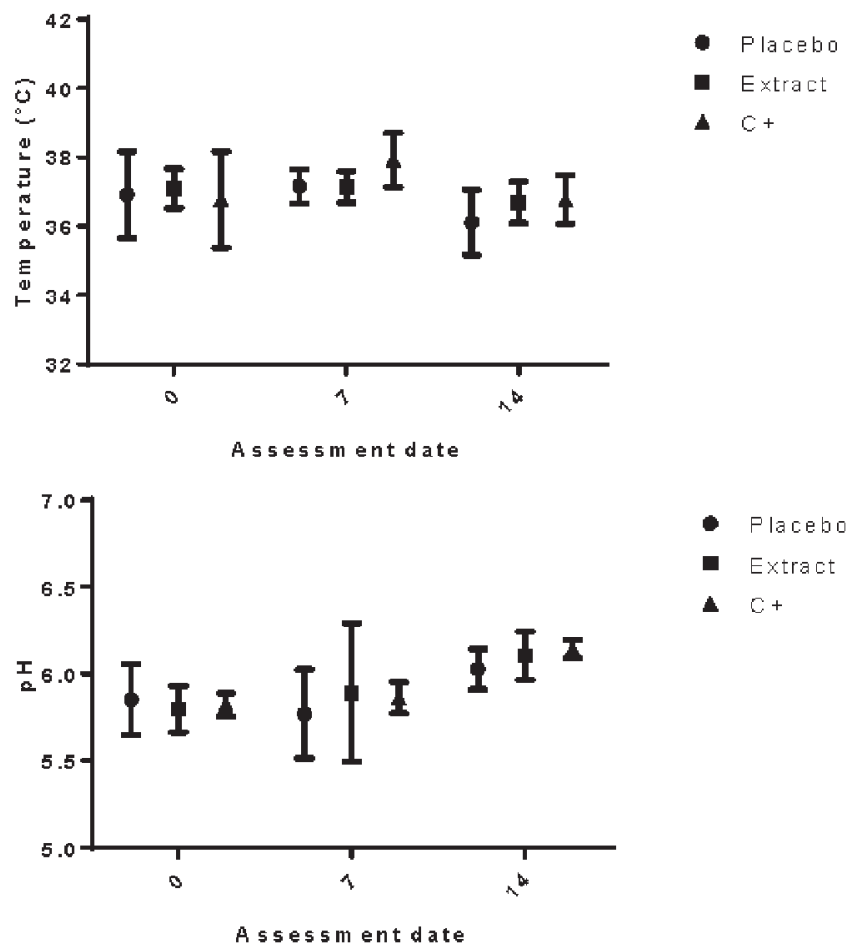

Fig.1. (A) Mean $( \pm S D$ ) of observed ear canal temperature, and (B) $\mathrm{pH}$ in the treatment groups: before treatment (day zero), after treatment (day 7), and on reassessment (day 14).

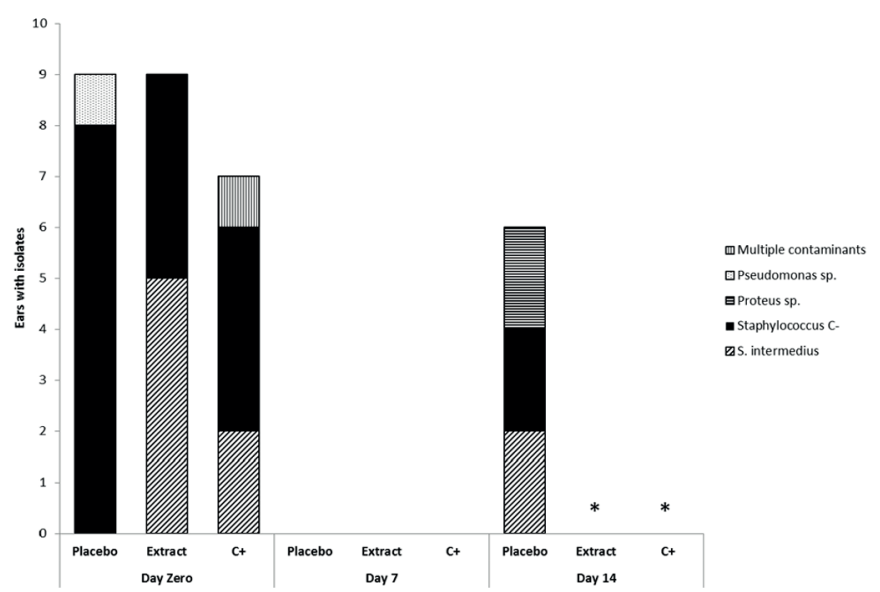

Fig. 2. Number of ears presenting bacterial isolates in each assessment day. * Indicates statistically significant difference when compared to the Placebo group in the same assessment day. and the results indicated no bacterial growth in any of the studied groups.

In addition, 14 days after treatment, the ears of the animals from all study groups were re-evaluated. Bacterial growth was detected in six ears treated with placebo; however, no bacterial growth was detected in the ears of the extract and $\mathrm{C}+$ groups. The results of bacterial isolation are shown in Figure 2.

\section{DISCUSSION}

In this study an aqueous wheat extract based product was shown to be effective in treating canine external otitis. To the authors knowledge, this is the first randomized, double-blind, placebo-controlled study to assess a plant extract in the treatment of canine otitis. This disease is usually treated through topical therapy with antimicrobial agents (Rougier et al. 2005). Concerns regarding antibiotic resistance press the search for alternatives (Lozina et al. 2010, Ziech et al. 2013), especially considering otitis, were both the causative agents and drugs used are the same in veterinary and human medicine (Lyskova et al. 2007, Malayeri et al. 2010). Wheat has been used for some time in wound healing and skin ointments (Tillmann et al. 2014), and immune-modulatory (Hyung et al. 2010), antioxidant (Souza et al. 2006), and antibiotic (Ribas et al. 2005, Godeiro et al. 2010) properties have been described. In our study, microbial clearing was particularly effective, and future studies should emphasize this aspect of the wheat extract treatment.

Some pre-clinical studies have been conducted regarding wheat extracts on external otitis, both infectious (Fontoura 2014) and noninfectious (Mueller 2011). These studies revealed the concentration used herein as effective and safe. Concerns regarding the high concentration of propylene influencing the outcome through its effect in clearing the accumulated wax, had been made (Mueller et al. 2013). None the less, the proposed dose was effective, and the bacterial clearing capability of the wheat extract could be clearly shown (Fig.2). However, propylene, though a common vehicle in otology products, has been shown to be toxic if used for long periods of time (Geller et al. 2010). In this light, though the wheat based product was effective, long term use has yet to be studied, and a reduction in propylene concentration may yield a safer product for this purpose.

Regarding the clinical signs of external otitis, all groups showed improvement after the onset of treatment (Table 1). Again, though some improvement was expected in the control group, due to the $75 \%$ propylene (Nuttall \& Cole 2004), the remission of almost all cases was surprising. Temperature and $\mathrm{pH}$ of the ear canal also responded similarly in all groups (Fig.1). These parameters are important for the establishment of pathogenic bacteria and/or fungi (Mueller et al. 2012, Mueller et al. 2013), but no correlation with infection was observed in our study. None the less, temperatures in all groups were slightly lower than normal, which is expected in patients suffering from external otitis (Yoshida et al. 2002), infectious or otherwise. Therefore, the rising temperatures in 
Table 1. Frequency of observed clinical parameters in the treatment groups: before treatment (day zero), after treatment (day 7), and on reassessment (day 14)

\begin{tabular}{|c|c|c|c|c|c|}
\hline Parameter & Day & Placebo* & Extract* & $\mathrm{C}+*$ & $P$ value \\
\hline \multirow[t]{3}{*}{ Itchiness } & zero & 8 & 5 & 3 & 0.078 \\
\hline & 7 & 6 & 5 & 3 & 0.391 \\
\hline & 14 & 2 & 1 & 1 & 0.749 \\
\hline \multirow[t]{3}{*}{ Foul odor } & zero & 3 & 4 & 3 & 0.851 \\
\hline & 7 & 0 & 1 & 1 & 0.362 \\
\hline & 14 & 0 & 1 & 0 & 0.325 \\
\hline \multirow[t]{3}{*}{ Pain } & zero & 3 & 3 & 4 & 0.860 \\
\hline & 7 & 2 & 2 & 0 & 0.315 \\
\hline & 14 & 0 & 1 & 0 & 0.355 \\
\hline \multirow[t]{3}{*}{ Erythema } & zero & 5 & 3 & 6 & 0.391 \\
\hline & 7 & 1 & 1 & 0 & 0.585 \\
\hline & 14 & 0 & 1 & 0 & 0.355 \\
\hline \multirow[t]{3}{*}{ Stenosis } & zero & 1 & 1 & 1 & 0.585 \\
\hline & 7 & 1 & 0 & 0 & 0.355 \\
\hline & 14 & 1 & 0 & 0 & 0.355 \\
\hline \multirow[t]{3}{*}{ Excess Wax } & zero & 9 & 9 & 10 & 0.585 \\
\hline & 7 & 1 & 0 & 1 & 0.355 \\
\hline & 14 & 1 & 1 & 0 & 0.585 \\
\hline
\end{tabular}

* Numbers represent how many observations of the parameter were made in each group $(\mathrm{N}=10)$ on each assesment date.

the $\mathrm{C}+$ group by day seven indicate an early recuperation from the ailment, however, by day 14 those ears treated with the extract had also normalized, unlike those treated with the placebo.

Regarding microbial isolation, coagulase-negative Staphylococcus spp. were the most prevalent bacteria (30\% of cases), followed by Staphylococcus intermedius (15\%), and Pseudomonas sp. (1.66\%). These are the usual infecting agents of external otitis, and the frequency and distribution were similar to what has been previously described (Oliveira et al. 2005, Lyskova et al. 2007).

In our study, the majority of parameters responded regardless of the treatment group, which indicates that antibiotic use may not be necessary in most cases, allowing for substitution with such products as the one suggested here. Especially in these infectious cases, the wheat extract was more effective than the placebo, yielding results similar to the positive control, eliminating and controlling the infection. In light of these results, supported by the preclinical trials (Mueller 2011, Fontoura 2014), Triticum aestivum seems to be safe and effective in the treatment of external otitis, and should be considered as an adjuvant for mainstream, antibiotic treatment. Additionally, with further studies this extract seems to have the potential to be the sole treatment used in some, if not most, cases of canine external otitis.

\section{CONCLUSIONS}

The results generated herein show that a $25 \%$ wheat extract solution is effective in the reduction of clinical and microbiological parameters of external otitis.

As the first clinical trial of its kind, we have demonstrated that traditional, antibiotic and anti-inflammatory based treatment may be overused, limiting its effectiveness when truly necessary, and most cases could be treated with the product described here.

Acknowledgements.- The authors thank CAPES and CNPq (305072/20129) for the financial support and research funding.; VetPharma ${ }^{\circledR}$ for the manipulation of the treatments; and ONG A4 for the use of their structure.

Conflict of interest statement.- The authors have no competing interests.

\section{REFERENCES}

Fontoura E.G. 2014. Rosmarinus officinalis L. e Triticum aestivum no tratamento da otite externa infecciosa. Dissertação de Mestrado em Medicina Veterinária, Sanidade Animal, Faculdade de Veterinária, Universidade Federal de Pelotas (UFPel), Pelotas, RS. 51p.

Geller M., Filho A.B., Cunha K.S.G., Slaibi E.B., Abreu C.S. \& Barbosa J.S.S. 2010. Avaliação imunodermatológica da resposta ao propilenoglicol e ao butilenoglicol - revisão bibliográfica sistemática. Revta Bras. Med. 67:234-239.

Godeiro J.R.G., Batista J.S., Reis P.F.C.C., Olinda R.G., Vale R.G., Calado E.B., Barros L.E.S., Oliveira A.F. \& Feijó F.M.C. 2010. Avaliação da atividade cicatrizante de creme à base de Triticum vulgare em feridas cutâneas de gatas submetidas à ovariossalpingohisterectomia. Acta Vet. Brasilica 4:78-85.

Hyung S.H., Jung-Hee J., Jae H.J., Jung S.C., Yoon J.K., Chan L., Sun H.L., Hyeong-Kyu L. \& Jongwon L. 2010. Water extract of Triticum aestivum L. and its components demonstrate protective effect in a model of vascular dementia. J. Med. Food 13:572-578.

Lozina L.A., Peichoto M.E., Boehringer S.I., Koscinczuk P., Granero G.E. \& Acosta O.C. 2010. Efficacy of Argentine propolis formulation for topical treatment of canine otitis externa. Arq. Bras. Med. Vet. Zootec. 62:13591366.

Lyskova P., Vydrzalova M. \& Mazurova J. 2007. Identification and antimicrobial susceptibility of bacteria and yeasts isolated from healthy dogs and dogs with otitis externa. J. Vet. Med. 54:559-563.

Malayeri G. Z., Jamshidi S. \& Salehi T.Z. 2010. Identification and antimicrobial susceptibility patterns of bacteria causing otitis externa in dogs. Vet. Res. Commun. 34:435-444.

Mueller E.N. 2011. Microclima do canal auditivo de cães e efeito de Rosmarinus officinalis L. e de Triticum vulgare no tratamento da otite externa experimental. Tese de Doutorado em Medicina Veterinária, Sanidade Animal, Faculdade de Veterinária, Universidade Federal de Pelotas, Pelotas, RS. 76p.

Mueller E.N., Bergmann L.K., Anciuti A.N., Tillmann M.T. \& Nobre M.O. 2012. Estudo da diferença das temperaturas retal e do canal auditivo de acordo com a conformação da concha acústica em cães. Semina, Ciênc. Agrárias 33:1907-1910.

Mueller E.N., Guiot E.G., Santin R., Meireles M.C.A., Schuch L.F.D. \& Nobre M.O. 2013. Efeito auxiliar do ceruminolítico na terapia tópica de cães (Canis lúpus familiaris) com otite externa ceruminosa. Ciênc. Anim. Bras. 14:59-64.

Nuttall T. \& Cole L.K. 2004. Ear cleaning: the UK and US perspective. Vet. Dermatol. 15:127-136.

Oliveira L.C., Medeiros C.M.O., Silva I.N.G., Monteiro A.J., Leite C.A.L. \& Carvalho C.B.M. 2005. Susceptibilidade a antimicrobianos de bactérias isoladas de otite externa em cães. Arq. Bras. Med. Vet. Zootec. 57:405408.

Plischke K.M. \& Pereira A.V. 2012. Etiopatogenia, diagnóstico e tratamento da otite externa canina: revisão. MedVep Derm. 2:188-195.

Ribas L.M., Nogueira C.E.W., Beira F.T.A., Albuquerque L.P.A.N. \& Kickhöfel I.A. 2005. Efeito cicatrizante do extrato aquoso de Triticum vulgare em feridas do tecido cutâneo de equinos. Hora Vet. 147:27-29.

Rougier S., Borell D., Pheulpin S., Woehrle F. \& Boisramé B. 2005. A comparative study of two antimicrobial/anti-inflammatory formulations in the treatment of canine otitis externa. Vet. Dermatol. 16:299-307.

Souza D.W., Machado T.S.L., Zoppa A.L.V., Cruz R.S.F., Gárrague A.P. \& Silva L.C.L.C. 2006. Ensaio da aplicação de creme à base de Triticum vulgare 
na cicatrização de feridas cutâneas induzidas em equinos. Revta Bras. Plantas Med. 8:9-13.

Tillmann M.T., Felix A.O.C., Mueller E.N., Felix S.R., Alves G.H., Ramos T.S., Freitag R.A., Fernandes C.G. \& Nobre M.O. 2014. Use of Triticum aestivum in open wound healing: a clinical, pathological and tensiometric assessment in the rabbit model. Arq. Bras. Med. Vet. Zootec. 66:17571761.
Yoshida N., Naito F. \& Fukata T. 2002. Studies of certain factores affecting the microenvironment and microflora of the external ear of the dog in health and disease. J. Vet. Med. Sci. 64:1145-1147.

Ziech R.E., Farias L.D., Balzan C., Ziech M.F., Heinzmann B.M., Lameira O.A. \& Vargas A.C. 2013. Atividade antimicrobiana do oleorresina de copaíba (Copaifera reticulata) frente a Staphylococcus coagulase positiva isolados de casos de otite em cães. Pesq. Vet. Bras. 33:909-913. 